\title{
KENNISDOCUMENT
}

\section{Tijdvertraging (time-lags) in regionale wateren}

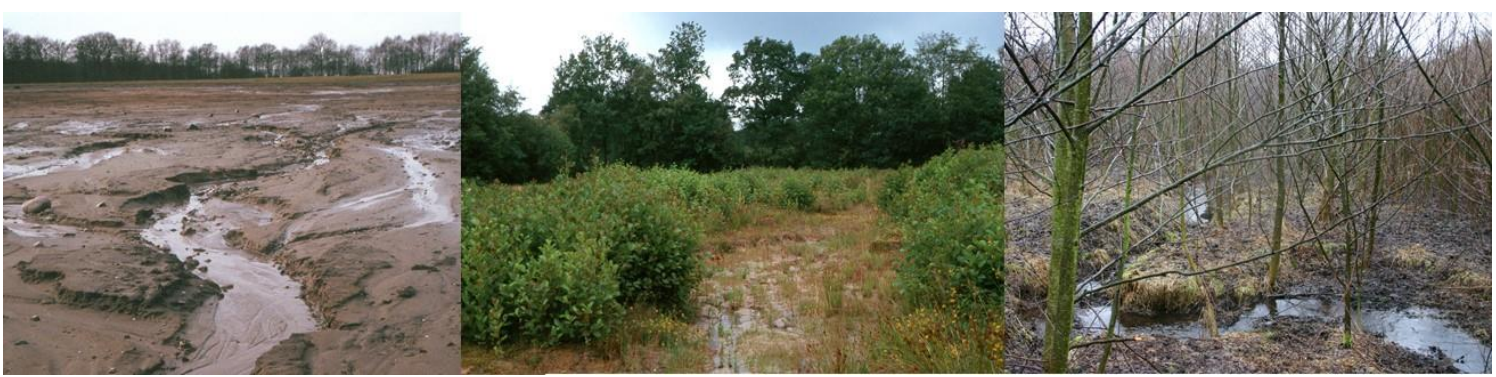

De ontwikkeling van een hersteld brongebied

Piet F.M. Verdonschot \& Ralf C.M. Verdonschot 


\section{Referaat}

Zowel het milieu als de soorten hebben tijd nodig om na een maatregel te ontwikkelen naar de nieuwe toestand. Sommige processen gaan snel en andere langzaam, sommige soorten komen snel en andere pas heel laat. Bij evaluatie van het effect van een maatregel moet rekening worden gehouden met deze tijdvertraging. Het opstellen van tussendoelen is hierbij een handig hulpmiddel. Ook moet rekening worden gehouden met de kans waarmee soorten terugkeren en dit kan aanleiding zijn om soorten te herintroduceren of landschappelijke barrières die verspreiding beperken ook in het herstelproject mee te nemen. Bij het monitoren van een herstelproject arriveren vaak eerst algemene en toevallige soorten, pas jaren later ontwikkelt zich de doelgemeenschap. Met doorlopende doelgerichte tijdreeksmonitoring van geschikte indicatoren van tussendoelen kan het ontwikkelingsproces worden steeds tussentijds worden geëvalueerd en waar nodig bijgesteld. De voortgang kan nauwkeurig worden gerapporteerd en bij afwijkingen kan worden bijgestuurd (adaptieve monitoring en beheer).

\section{Auteurs}

Piet F.M. Verdonschot \& Ralf C.M. Verdonschot (correspondentie: piet.verdonschot@wur.nl)

\section{Opdrachtgever}

Kennisimpuls waterkwaliteit (KIWK)

\section{Projectgroep}

Gebruikerscommissie Kennisimpuls waterkwaliteit Systeemkennis ecologie en waterkwaliteit

\section{Leesgroep}

Marcel van den Berg (RWS), Bas van der Wal (STOWA), Nikki Dijkstra (HDSR)

\section{Wijze van citeren}

Piet F.M. Verdonschot \& Ralf C.M. Verdonschot (2021). Tijdvertraging (time-lags) in regionale wateren. Kennisdocument Kennisimpuls waterkwaliteit, Zoetwaterecosystemen, Wageningen Environmental Research, Wageningen UR, Wageningen. 19 pp.

\section{Trefwoorden}

degradatie, hersteltijd, respons, kolonisatie, ecosysteemontwikkeling

\section{Beeldmateriaal}

Piet Verdonschot

DOI: https://doi.org/10.18174/544235

Dit project is uitgevoerd in opdracht van de KennisImpuls WaterKwaliteit (KIWK).

(C) 2021 Zoetwaterecosystemen, Wageningen Environmental Research

- Overname, verveelvoudiging of openbaarmaking van deze uitgave is toegestaan mits met duidelijke bronvermelding.

- Overname, verveelvoudiging of openbaarmaking is niet toegestaan voor commerciële doeleinden en/of geldelijk gewin.

- Overname, verveelvoudiging of openbaarmaking is niet toegestaan voor die gedeelten van deze vitgave waarvan duidelijk is dat de auteursrechten liggen bij derden en/of zijn voorbehouden.

Wageningen Environmental Research aanvaardt geen aansprakelijkheid voor eventuele schade voortvloeiend uit het gebruik van de resultaten van dit onderzoek of de toepassing van de adviezen. 


\section{Inhoud}

Inhoud

2 Tijdvertraging in abiotische herstelprocessen 3

$\begin{array}{lll}2.1 & \text { Inleiding } & 3\end{array}$

\begin{tabular}{ll}
2.2 & Reis- en verblijftijd \\
\hline
\end{tabular}

$\begin{array}{ll}2.3 \quad \text { Nalevering } & 4\end{array}$

$\begin{array}{lll}2.4 & \text { Overige biofysische processen } & 4\end{array}$

3 Tijdvertraging in biologisch herstel $\quad 5$

$\begin{array}{lll}3.1 & \text { Kolonisatie en vitsterven } & 5\end{array}$

$\begin{array}{lll}3.2 & \text { Kenmerken van soortlevenscycli en populatie-ontwikkeling } & 6\end{array}$

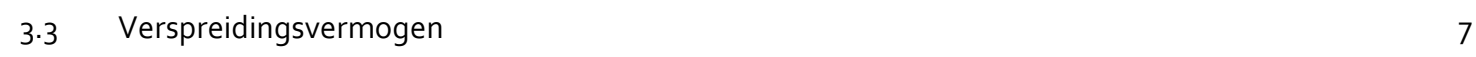

$\begin{array}{ll}3.4 & \text { Migratie en dispersie }\end{array}$

$\begin{array}{ll}3.5 & \text { Gebiedsgrootte (oppervlak-soortaantal relatie) }\end{array}$

3.6 Connectiviteit (landschapsconfiguratie) 8

3.7 Prioriteitseffecten (remmende mechanismen) en andere biologische interacties en functionele rollen

$4 \quad$ Hersteltijd en mate van herstel $\quad 9$

5 Maatregelen in de context van tijdvertraging $\quad 12$

5.1 Maak tijdvertraging onderdeel van het hersteltraject $\quad 12$

$\begin{array}{ll}5.2 \text { Herintroductie } & 12\end{array}$

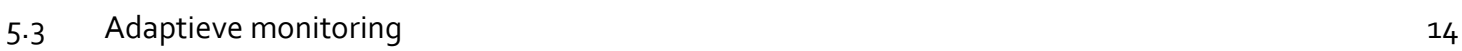

$6 \quad$ Literatuur $\quad 15$ 


\section{Inleiding}

Er zijn inmiddels veel KRW herstelmaatregelen uitgevoerd maar van de effecten is nog weinig zichtbaar. Een belangrijke vraag hierbij is of dit komt door een vertraging in het herstelproces. En de vraag of het dan komt door een time-lag. Time-lag, 'degradatie- en hersteltijd' of tijdvertraging is in de ecologie gedefinieerd als de tijd tussen een activiteit, zoals een herstelingreep of verstoring (bijvoorbeeld een droogte, calamiteit of ander extreem), en de reactie op die actie, zoals de biofysische aanpassing van het ecosysteem aan de ingreep of verstoring (Meals et al. 2010). In andere woorden: tijdvertraging geeft de hoeveelheid tijd aan die een ecosysteem nodig heeft om in een dynamisch evenwicht te komen na een verstoring of na een herstelingreep (aangepast naar Watts et al. 2020). De aanname dat er een directe oorzakelijke relatie is tussen het milieu en de verspreiding van soorten is inmiddels verlaten. Het is gebleken dat de aanwezigheid van een soort niet alleen afhankelijk is van de heersende maar ook van de historische omstandigheden, van de levenskenmerken van de soort en van biotische interacties. De vertraagde respons van soorten en ecosystemen op verandering, verstoring of herstelingreep, is zichtbaar in de vertraging in het verdwijnen van soorten bij de achteruitgang van de kwaliteit van het milieu (Heywood et al. 1994) of in de vertraging in de terugkeer na herstel (Cristofoli et al. 2010). De tijd vertraagde achteruitgang na verstoring wordt de uitstervingsschuld of 'extinction debt' (Kuussaari et al. 2009, Figueiredo et al. 2019) genoemd, het tijdvertraagde herstel wordt het kolonisatiecrediet of 'colonisation credit' genoemd (Jackson \& Saxs 2010, Kolk et al. 2017).

In dit document gaat het om het effect van de herstelmaatregel(en) op de milieu-omstandigheden (de abiotische responstijd) en de biologische responstijd. Bij herstel is het van belang te weten of de ecosysteemverandering nog komt of dat er aanvullende actie nodig is. Hierbij zijn twee vragen van belang:

1. Wat zijn de oorzaken van de vertraagde respons van de ecosystemen en hoe lang duurt die vertraging?

2. Als we de oorzaak van tijdvertraging kennen, zijn er dan mogelijkheden om de vertragingstijd te verkorten?

De tijdvertraging die optreedt voor beleid- en planvorming, dus de tijd die voorafgaat aan het daadwerkelijk uitvoeren van de maatregel of maatregelen, wordt in deze factsheet niet meegenomen. Als een maatregel is uitgevoerd zijn een aantal factoren van invloed op de snelheid waarmee een ecosysteem zich kan ontwikkelen of herstellen naar een gewenste toestand:

A. Abiotisch

- De tijd nodig voor het verdwijnen van de historische erfenissen.

- De tijd nodig om voor het ontstaan van het beoogde milieu en habitats (vertraging in abiotische herstelprocessen).

B. Biologisch

- Kolonisatie en uitsterven.

- Soortlevenscycli en populatie-ontwikkeling.

- Verspreidingsvermogen.

- Gebiedsgrootte.

- Connectiviteit (landschapsconfiguratie).

- Prioriteitsmechanismen.

In de meeste gevallen is er sprake van een combinatie van deze factoren. Zo is de bereikbaarheid voor beoogde soorten pas relevant als de habitat(s) voor die soorten zich heeft ontwikkeld. In dit habitat moet ook de voedselvoorziening voor de soort op orde zijn, en vervolgens moet zich een duurzame populatie opbouwen. Tijdens al deze fasen kan ondertussen sprake zijn van remmende factoren zoals concurrentie en competitie ('priority effects'). 


\section{Tijdvertraging in abiotische herstelprocessen}

\subsection{Inleiding}

Tijdvertraging tussen het nemen van een maatregel en het moment dat het abiotische effect in het ontvangende oppervlaktewater zichtbaar wordt is sterk afhankelijk van de aard en omvang van de maatregel en de gerelateerde processen. Verschillende abiotische milieu-omstandigheden zijn van invloed op de tijdvertraging. Bijvoorbeeld het uitrasteren van vee langs beken in de VS liet na circa 3 maanden een effect in de verlaging van de nutriënten- en fecale belasting zien (Meals 2001) en het effect van de aanleg van een bosbuffer liet 10 jaar na aanplant een vermindering in het nitraatgehalte zien (Newbold et al. 2008).

Maatregelen kunnen op ruimtelijk verschillende plaatsen worden genomen zoals direct in het waterlichaam of in het aanvoergebied of in het bovenstroomse gebied. Ruimtelijke schaal speelt een grote rol waarbij naar verwachting een kleinere ruimtelijk schaal ook een kortere tijdvertraging op zou moeten leveren maar dat blijkt lang niet altijd zo te zijn (Meals et al. 2010). Hierna worden ter verduidelijking enkele voorbeelden gegeven van abiotische tijdvertraging. Zo volgt de watertemperatuur met een vertraging van uren tot dagen de luchttemperatuur afhankelijk van de watermassa (Stefan \& Preud'homme 1993); een kortdurende tijdvertraging. Wanneer een stuw uit een beek wordt gehaald treden geomorfologische processen op, met lokaal sediment transport, bovenstroomse erosie en benedenstroomse sedimentatie, die circa 1-5 jaar nemen om tot een nieuw evenwicht te komen (Simon 1992, Doyle et al. 2005). Een vermindering van bemestingsniveau leverde pas na 28 jaar een fosforrespons op (Zhang et al., 2004) terwijl in kleine stroomgebieden bij het uitrasteren van vee de fosfor-, stikstof- en Escherichia coli gehalten al na minder dan 1 jaar waren verminderd (Meals 2001). De tijdvertraging van het opheffen van belasting met $E$. coli is relatief kort omdat de bacterie maar korte tijd (waarschijnlijk enkele maanden) overleeft (Crane et al. 1983, Sherer et al. 1992).

Sand-Jensen (2017) namen in het meer Fure (DK) waar dat bij een 25-voudige fosforbelasting (sedimentoplading) t.o.v. de natuurlijke situatie het 40 jaar duurde voordat het eutrofiëringseffect in de fosforconcentraties in het oppervlaktewater zichtbaar werd. Pas 5 jaar na de sterke vermindering van de fosforbelasting werden de eerste effecten zichtbaar en 34 jaar later bleken de concentraties nog steeds aanmerkelijk hoger dan meer dan 80 jaar daarvoor ondanks de lage toevoer. Verschillende fysische en chemische processen beïnvloeden de respons en daarmee de tijdvertraging.

\subsection{Reis- en verblijftijd}

Fysische processen, zoals slibafspoeling en sedimenttransport, en chemische processen, zoals de sorptiekinetiek in bodems en waterbodems vertragen de verplaatsing van verontreinigende stoffen die in opgeloste vorm sneller zouden verplaatsen. De snelheid waarmee het grondwater zich verplaatst (reistijd) bepaald in sterke mate de snelheid waarmee veranderingen in de belasting met verontreinigende stoffen in ontvangende oppervlaktewateren optreedt. Vaak is er sprake van specifieke stofroutes waarlangs stoffen getransporteerd worden. Bij afspoeling over land betreft het transport van slibdeeltjes (particulair materiaal) en opgeloste stoffen, zoals fosfor, stikstof en ammonium. De nutriënten worden ook bij ondiepe uitspoeling verplaatst terwijl bij transport door dieper grondwater het vooral nitraat betreft (Jarvie et al. 2008). Het transport van toxische stoffen wordt door sorptie aan bodemmateriaal eveneens vertraagd waardoor de transportsnelheid lager is dan de snelheid van de grondwaterverplaatsing (Rao et al. 1985). $\mathrm{Bij}$ opgeloste stoffen spelen de route, de transportsnelheid of reistijd en de verblijftijd een belangrijke rol.

Sloten en drains transporteren opgeloste stoffen snel, het transport van slib met gebonden nutriënten is langzamer en transport van opgeloste stoffen via het grondwater kan nog trager verlopen afhankelijk van de diepte, de weglengte en de aard van het bodemmateriaal. Dergelijk transport kan jaren, decades tot eeuwen duren (McMahon et al. 2006). Hierbij moet in gedachten worden gehouden dat door menging het nog circa driemaal zo lang kan duren om circa 95\% van de belasting kwijt te raken (McGuire \& McDonnell 2006) of soms nog langer (Godsey et al. 2010). Michel (2004) berekende dat het 20-25 jaar duurt voordat $>50 \%$ van een conservatieve opgeloste stof (een stof die in een waterlichaam alleen verandert door mengen en diffusie) uit het stroomgebied van de bovenlopen van de rivieren Missouri en Ohio (VS) was uitgespoeld. In Engeland was 12-15 jaar na implementatie van nitraatreductie maatregelen, nog geen effect waarneembaar (Worrall et al. 2009). 
In een beek worden opgeloste stoffen vele malen sneller getransporteerd dan slib. Na reductie van de nutriëntengift was het effect tijdvertraagd afhankelijk van de aard van de stof, de binding aan slib en de transportroute en -snelheid. De transportsnelheid hangt voor een belangrijk deel samen met de hydrologie. Slib kan worden verplaatst maar kan ook worden afgezet op de oever en veel later weer worden ge-erodeerd en verder verplaatst. Dergelijke sedimentverplaatsingen kunnen tientallen tot honderden jaren in beslag nemen (Schumm 1977, Trimble 2010). Sediment kan door de aanleg van stuwen en andere obstructies geleidelijk over lange tijd zijn afgezet waarbij de overstroomde oevers ophoogden. Na verwijdering van een stuw of dam kan het gesedimenteerd materiaal weer geleidelijk eroderen en leiden tot belasting van het systeem benedenstrooms (Burroughs et al. 2009).

In meren speelt de verblijftijd een belangrijke rol in de snelheid waarmee nutriëntenreductie, vooral door nalevering uit de waterbodem, plaatsvindt.

\subsection{Nalevering}

Een ander aspect van tijdvertraging bij herstel is de nalevering van nutriënten uit de waterbodem. Dit effect wordt ook wel het erfeniseffect genoemd. Gebeurtenissen in het verleden werpen hun effect soms ver na dato vooruit. Door de sterke binding van fosfor aan andere mineralen ontstaat een zogenaamde 'fosforbuffer'. Nadat een sterke oplading heeft plaats gevonden kan het fosfor nog over lange perioden (tijdvertraagd) worden nageleverd (Froelich 1988, Schippers et al. 2006). Dergelijke binding en nalevering is uitgebreid beschreven voor land-water transport (Haygarth et al. 2005, Ulen \& Jakobsson 2005), voor beken en rivieren (Mainstone \& Parr 2002, Withers \& Jarvie 2008, Neal et al. 2010), voor meren (Marsden 1989) en voor wetlands (Reddy et al. 1995, 1999, Smolders et al. 2006). Nalevering treedt op als opgeladen sedimenten eroderen of als de bindingscapaciteit van de bodems wordt overschreden. Het inunderen van droge gronden kan ook tot nalevering leiden. Raakt een waterbodem zuurstofloos dan treedt eveneens nalevering op (Marsden 1989). Fosfornalevering uit een waterbodem kan jaren na verlaging van de toevoer nog blijven optreden, naar schatting circa 20-70 jaar in diepe (Dørge \& Windolf 2003, GenkaiKato \& Carpenter 2005, Schippers et al. 2006) en circa 15-20 jaar in ondiepe meren (Phillips et al. 2005, Jeppesen et al. 2005, 2007).

\subsection{Overige biofysische processen}

Wanneer actief ingegrepen wordt in een bestaand systeem, zoals het graven van een nieuwe, kronkelende beekbedding, dan ontstaat een maagdelijk systeem zonder enige organismen. Van bodemmicroben tot toppredatoren moet het systeem zich ontwikkelen. Echter het begin van biologische ontwikkeling hangt in belangrijke mate samen met hoeveel tijd de abiotische processen nemen. Is de beekbedding niet gegraven conform de afvoerkarakteristiek van de beek dan zullen erosie- en sedimentatieprocessen de bedding eerst verder vormen en dat geeft een tijdelijke instabiliteit die voor de biologie vertragend werkt. Waren de oevers van deze nieuwe bedding kaal en wordt het beeksysteem overgelaten aan een natuurlijke ontwikkeling dan zal er uiteindelijk bos ontwikkelen. Deze bosontwikkeling neemt tijd in beslag. Pas als de beschaduwing voldoende is, de eerste takken vallen en een voldoende hoeveelheid blad wordt aangevoerd kan het natuurlijke beekleven volledig terugkeren. Dat betekent in de praktijk een hersteltijd zelfs meerdere decennia of nog langer kan duren maar dit hoeft niet altijd het geval te zijn.

Vergelijkbare vertraging treedt op in nieuw gegraven plassen waar nog geen sprake is van bodemleven. Het benthos speelt een belangrijke rol in de voedselwebben van stilstaande wateren, echter eerst zal er een onderwaterbodemprofiel moeten ontwikkelen voordat de benthische component een rol kan gaan spelen. Wanneer gekozen wordt voor herstel door gebruik te maken van natuurlijke processen zal een periode ontstaan waarin het systeem verandert en dus dynamisch is waardoor herkolonisatie door gewenste soorten nog niet op gang kan komen. Neem als voorbeeld het stoppen van maaibeheer in een beek om zo op termijn het doorstroomde profiel te verkleinen. Er is tijd nodig om de gewenste verlandingsen sedimentatieprocessen hun 'herstelwerk' te laten uitvoeren. Het is onbekend hoeveel tijd daarvoor nodig is mede omdat het erg context afhankelijk is.

Korte termijn verbeteringen kunnen op langere termijn ook weer verdwijnen. Dergelijke tijdelijke veranderingen treden bijvoorbeeld op bij het afvissen van meren. Søndergaard et al. (2007) concludeerden op basis van 70 herstelprojecten dat in projecten waar vis was verwijderd de troebele toestand na circa 810 jaar weer was teruggekeerd en herhaling van de maatregel noodzakelijk was. 


\section{Tijdvertraging in biologisch herstel}

\subsection{Kolonisatie en uitsterven}

De theorieën over tijdvertraging zijn gebaseerd op kennis van soort-oppervlak relaties, metapopulaties en eilandtheorie. De soort-oppervlak relatie gaat uit van de draagkracht van een gebied voor het aantal soorten. Hoe kleiner het gebied des te minder soorten er samen voor kunnen komen. Als er bijvoorbeeld na verstoring meer soorten in een klein gebiedsrestant achterblijven dan het aantal dat te verwachten is op basis van een ongestoord fragment van vergelijkbare grootte (waarin soorten in dynamisch evenwicht zijn), dan duidt dit op een uitstervingsschuld. De boventallige soorten zullen geleidelijk verdwijnen wat we ook waarnemen in veel snippers natuur in ons land waar het verdwijnen van soorten nog steeds langzaam voortschrijdt. Naast oppervlak speelt ook draagkracht van het gebied een rol. Vergelijkbaar is het verschijnsel dat in een groot hersteld leefgebied in vergelijking met een natuurlijk uitontwikkeld gebied minder soorten voorkomen (Krauss et al. 2010, Lira et al. 2019). In dit voorbeeld zijn nog niet alle soorten gearriveerd. Dit duidt op een kolonisatie- of soortkrediet. In de eiland- en metapopulatie theorieën wordt het dynamisch evenwicht in aantal soorten bepaald door mechanismen achter kolonisatie en uitsterven.

$\mathrm{Na}$ herstel treden dezelfde mechanismen in werking. Kolonisatie is de opeenvolging van gebeurtenissen die leidt tot de vestiging van individuen, populaties, soorten of hogere taxa op plaatsen waar deze (tijdelijk) niet aanwezig waren. Kolonisatie van nieuwe gebieden is een resultaat van dispersiesucces (Verdonschot 2021). Of een soort zich vervolgens in de nieuwe habitat kan handhaven hangt af van de geschiktheid van de abiotische en biotische omstandigheden in de nieuwe habitat (bijvoorbeeld de juiste temperatuur, voldoende zuurstof in het water, voldoende voedsel). Nieuwe soorten koloniseren het herstelde water en de successie komt op gang. Bij het verwijderen van stuwen en dammen uit rivieren bleek bijvoorbeeld dat het herstel van de vegetatie in de eerste 10 jaar na verwijdering vrij stochastisch, zonder duidelijke richting van successie, verliep en dat zich na circa 30 jaar een oeverbos had ontwikkeld (Orr 2002).

Er zijn 3 hoofdtheorieën over toestanden waarin ecosystemen kunnen verkeren en de ontwikkeling die daaraan voorafgaat (Tabel 3.1): evenwichten, multiple evenwichten en niet-evenwichten. Het verschil tussen deze theorieën is dat de discontinuïteit, onvoorspelbaarheid, stochasticiteit in soortensamenstelling en functioneren van links naar rechts in tabel 1 toeneemt.

Tabel 3.1: Algemene theorieën over de structuur en het functioneren van systemen in de tijd al dan niet na verstoring (naar Suding \& Gross, 2006).

\begin{tabular}{|c|c|c|c|}
\hline & Evenwichten & Multiple evenwichten & Niet-evenwichten \\
\hline Aanname & $\begin{array}{l}\text { climax, één richting van } \\
\text { ontwikkeling, continue }\end{array}$ & $\begin{array}{l}\text { evenwicht, meerdere } \\
\text { richtingen, discontinu }\end{array}$ & $\begin{array}{l}\text { blijvend niet- } \\
\text { evenwicht, zonder } \\
\text { richtingen, discontinu }\end{array}$ \\
\hline $\begin{array}{l}\text { Permanente } \\
\text { toestand(en) }\end{array}$ & één & meerdere & geen \\
\hline Ontwikkeling & convergent & $\begin{array}{l}\text { abrupte veranderingen, } \\
\text { instortingen }\end{array}$ & $\begin{array}{l}\text { divergent, 'random', } \\
\text { cyclisch }\end{array}$ \\
\hline Voorspelbaarheid & $\begin{array}{l}\text { hoog (gebaseerd op } \\
\text { soorteigenschappen) }\end{array}$ & $\begin{array}{l}\text { intermediair (mogelijk } \\
\text { maar moeilijk) }\end{array}$ & $\begin{array}{l}\text { laag (kans en historie } \\
\text { van belang) }\end{array}$ \\
\hline Belangrijke factoren & $\begin{array}{l}\text { soortinteracties, } \\
\text { ecosysteemontwikkeling }\end{array}$ & $\begin{array}{l}\text { begintoestand, } \\
\text { positieve } \\
\text { terugkoppelingen, } \\
\text { positie in het landschap }\end{array}$ & $\begin{array}{l}\text { toevallige verspreiding } \\
\text { soorten, stochasticiteit }\end{array}$ \\
\hline Referentie & $\begin{array}{l}\text { Clements 1916, Odum } \\
1969\end{array}$ & $\begin{array}{l}\text { Gleason 1917, } \\
\text { Sutherland } 1974\end{array}$ & Pickett et al. 1987 \\
\hline
\end{tabular}

In de evenwichtstheorie spelen soortinteracties, levensstrategieën en de voorspelbaarheid van het milieu de hoofdrol. De voorspelbaarheid neemt vooral af naarmate onregelmatige dynamiek en stochastische processen vaker en minder voorspelbaar optreden (Cornell \& Lawton 1992). Parallel aan de afname van de voorspelbaarheid verminderen het aantal en de intensiteit van soortinteracties en worden ontwikkelingsprocessen veranderlijker (Fisher 1983, Hobbs \& Harris 2001). 
Het voorspellen van de ontwikkelingsrichting van een te herstellen ecosysteem is moeilijk omdat het afhankelijk is van de dynamiek in milieu en ecologische interacties die optreden op verschillende schalen in ruimte en tijd (Tabel 3.2). Pickett et al. (1989) maakten daarom onderscheid tussen een snelle en langzame ecosysteemrespons in relatie tot het schaalniveau. Snelle respons treedt op het niveau van het individu op terwijl langzame respons op de schaal van de ecoregio verloopt. Door de opeenvolging van ontwikkelingsstadia in onderlinge afhankelijkheid kan de totale tijdsvertraging een aantal jaren duren. Daarom dient in de doelstelling de bij het gewenste (latere) successiestadium behorende tijdvertraging meegenomen te worden.

Tabel 3.2: Temporele en ruimtelijke schalen bij kolonisatie (Sheldon 1984, Gore \& Milner 1990).

\begin{tabular}{|l|l|l|l|}
\hline Tijd & Kort $(<\mathbf{1}$ mnd) & $\begin{array}{l}\text { Intermediair } \\
\mathbf{( 1} \text { generatie - enkele } \\
\text { jaren })\end{array}$ & $\begin{array}{l}\text { Lang } \\
\mathbf{( > 5 0} \text { jaren })\end{array}$ \\
\hline Kort $(<10 \mathrm{~m})$ & nabije habitats & litorale zones & - \\
\hline Intermediair $(0.1-100 \mathrm{~km})$ & $\begin{array}{l}\text { langzaam stromende } \\
\text { trajecten; litorale zones }\end{array}$ & $\begin{array}{l}\text { gegraven meren; } \\
\text { herstelde beektrajecten; } \\
\text { leeftijd/stadium } \\
\text { gebonden beweging }\end{array}$ & $\begin{array}{l}\text { geïntroduceerde } \\
\text { soorten? }\end{array}$ \\
\hline Lang $(>100 \mathrm{~km})$ & - & soort migratie & $\begin{array}{l}\text { continent en eiland } \\
\text { kolonisatie; } \\
\text { geïntroduceerde soorten }\end{array}$ \\
\hline
\end{tabular}

Een ander aspect wat niet onder tijdvertraging valt maar wel van belang is, is het niet volledig op orde zijn van de nagestreefde milieu-omstandigheden of het niet aansluiten van het herstelontwerp bij de ter plaatste behorende natuurlijke processen. In beide gevallen zal wel een ontwikkeling op gang komen na uitvoering van de maatregel(-en), maar gaat de ontwikkeling afwijken van het gestelde doel. Een voorbeeld is de aanleg van natuurvriendelijke oevers die vaak in de eerste jaren na aanleg er biodivers uitzien met een snelle opeenvolging van en variatie in van soorten. Daarna echter heeft het proces van verslibbing de oever zover veranderd dat zich een eenvormige rietkraag of liesgraszone ontwikkeld. Vergelijkbaar tegengestelde ontwikkelingen vinden plaats als er geen natuurlijk peil aanwezig is en toch een natuurlijke oever wordt nagestreefd. Hier is een ecologische systeemanalyse op $z^{\prime} n$ plaats die rekening houdt met alle factoren (stressoren).

\subsection{Kenmerken van soortlevenscycli en populatie-ontwikkeling}

De respons van soorten op veranderingen die leiden tot tijdvertraging wordt beïnvloed door mechanismen op het niveau van individuen, populaties en metapopulaties. Op het niveau van het individu spelen eigenschappen zoals levensduur en habitatspecificiteit een belangrijke rol. Zo zullen kortlevende soorten ook kortere tijdvertragingen laten zien m.a.w. ze verdwijnen sneller bij verstoring en keren sneller terug na herstel. Daarentegen is de respons in de tijd op veranderingen van langlevende soorten langzamer omdat relatief weinig generaties worden getroffen door de verandering (Krauss et al. 2010). Vergelijkbaar zullen veranderingen in een waterlichaam niet altijd een onmiddellijk effect laten zien op de aanwezige soorten met een lage habitatpreferentie omdat deze tolerante of ubiquistische soorten weinig kieskeurig zijn en wisselen in habitat. Dit treedt ook op na herstel waarbij de ubiquistische soorten nieuwe of herstelde wateren snel innemen. Soorten met meer specifieke habitateisen zullen veel sneller reageren op verstoring en verdwijnen terwijl na herstel de terugkeer veel langer zal duren.

Op populatieniveau is tijdvertraging afhankelijk van kenmerken die de populatie-ontwikkeling sturen zoals de levensduur, vitaliteit, omvang en populatie-opbouw. Soorten met kleine populaties en een trage populatie-ontwikkeling hebben een verhoogd risico op lokaal uitsterven en hun respons op verstoring is groot. Grote populaties met een snelle ontwikkeling blijven veelal langer aanwezig en hun respons op herstel is eveneens snel.

Watts et al. (2020) gebruiken een eenvoudig indeling om de mechanismen hanteerbaar te maken. Ze onderscheiden drie groepen soorten: generalisten, specialisten en gevoelige soorten. De generalist reageert snel op verandering en vertoont een korte tijdsvertraging. De generalist heeft weinig habitateisen, is tolerant, heeft een relatieve korte levensduur, een hoge reproductiesnelheid en verspreidingscapaciteit 
en is relatief abundant. De specialist heeft een specifieke habitatpreferentie, een lange levensduur met een lage reproductiesnelheid en een zwakke verspreidingscapaciteit. De specialist heeft een lange tijdsvertraging bij veranderingen in het milieu. De gevoelige soort komt als kleine, geïsoleerde populaties voor in een bijzondere habitat, heeft een kortere tot lange levensduur met een lage reproductiesnelheid en zwakke verspreidingscapaciteit. De gevoelige soorten met een korte levensduur zijn extra kwetsbaar voor verandering omdat ze snel verdwijnen met een geringe kans op herkolonisatie van buitenaf. De langer levende gevoelige soorten zullen langer overleven na verandering naar op den duur toch verdwijnen. De gevoelige soorten zijn de meest kwetsbare van de drie en zouden in het beheer prioriteit moeten krijgen. Dit sluit aan op de algemene observatie dat kolonisatie en populatieopbouw sneller verlopen bij r-strategen (veel nakomelingen, korte generatietijd) dan bij K-strategen (weinig nakomelingen, lange generatietijd).

\subsection{Verspreidingsvermogen}

Op het niveau van een metapopulatie wisselen individuen tussen populaties uit. Deze uitwisseling wordt bepaald door het verspreidingsvermogen of de dispersiecapaciteit van een soort, de afstand en ruimtelijke samenstelling (m.a.w. de configuratie van het landschap (connectiviteit) die moet worden overbrugd tussen twee deelpopulaties uit de metapopulatie) en mechanismen die werken op individueel- en populatieniveau. Over het algemeen zijn soorten die voorkomen in goed verbonden populaties beter bestand tegen uitsterven en blijven na (lokale) verstoringen langer aanwezig omdat individuen uit nabije populaties de verstoorde milieus weer snel bezetten. Er treedt bij goede verbindingen uitwisseling van genetisch materiaal plaats en lokaal verdwenen populaties kunnen snel worden aangevuld, ook na herstel.

\subsection{Migratie en dispersie}

Verplaatsing van dieren en planten kan in twee hoofdgroepen worden onderverdeeld, namelijk migratie en verspreiding (dispersie). Migratie is de beweging van een organisme over korte afstand binnen de populatie, de habitat of de biotoop, die plaats vinden met een regelmatige periodiciteit, een groot deel van de populatie behelst en bestaat uit gerichte bewegingen tijdens sommige stadia van de levenscyclus (Northcote 1998). Migratie betreft vooral de gerichte bewegingen van een organisme tussen functiegebieden, zoals de paai-, opgroei- en overwinteringsgebieden bij vissen.

Dispersie betreft voornamelijk de ongerichte of exploratieve bewegingen van organismen, waarbij de netto afstand tussen individuen in de (deel-)populatie groter wordt. Bij dispersie verplaatst het organisme zich naar een andere populatie, locatie of habitat. De vorm van het organisme kan verschillen, bijvoorbeeld als adult, ei of plantendeel. De dispersiecapaciteit is het vermogen van een soort om zich te verplaatsen, zoals het vermogen tot vliegen over een bepaalde afstand. Dispersie vindt plaats voor het vinden van voedsel, een partner, om andere gebieden in dezelfde of andere wateren te koloniseren of om ongeschikte condities te overleven (Malmqvist 2002) en kan actief of passief verlopen.

Dispersie is van belang voor het behoud van zoetwatersoorten op de lange termijn, omdat de meeste zoetwaterhabitats tijdelijk bestaan in relatie tot de levensduur (evolutionair bezien) van soorten (Bilton et al. 2001). Dispersie is dan ook een 'long term persistence trait' (Malmqvist 2002); als soorten zich goed kunnen verspreiden kunnen ze op lange termijn overleven.

\subsection{Gebiedsgrootte (oppervlak-soortaantal relatie)}

Jähnig et al. (2010) concludeerden na analyse van verschillende beekherstelprojecten dat herstel van korte beektrajecten meestal onvoldoende is om veranderingen in de macrofaunagemeenschap te verkrijgen. Feld et al. (2011) concludeerden dat het effect van het kleinschalig aanbrengen van substraattypen, zoals dood hout, grind of stenen, vaak in het niet valt t.o.v. grootschalige geomorfologische en fysisch-chemische processen. Beide voorbeelden sluiten aan bij de vraag of het herstelde beektraject, de sloot, plas of het meer voldoende ruimte biedt voor het ontwikkelen en handhaven van een duurzame populatie. Het minimum voor een duurzame populatie is een populatie die ook in geïsoleerde toestand een kans van uitsterven heeft die kleiner is dan $5 \%$ in 100 jaar. Als een populatie een te klein 'leefgebied' heeft dan leidt dit tot een vermindering van de hoeveelheid erfelijke variatie (genetische erosie), een afname van de vitaliteit van nakomelingen door inteelt en een verminderde productie van propagules (zaden, eieren, plantendelen). Daarnaast dient een 'leefgebied' alle habitats van voldoende kwaliteit te bevatten die de populatie tijdens het voltooien van de volledige levenscyclus nodig heeft. Bij beken maar ook rond 
laagveenwateren zijn bijvoorbeeld de opgaande bestanden van bomen en struiken die insecten nodig hebben om succesvol te paren.

\subsection{Connectiviteit (landschapsconfiguratie)}

Het uiteenvallen van geschikte leefmilieus, biotopen of habitats (hierna steeds met habitat aangeduid) vormt voor een soort een belangrijk knelpunt voor het duurzaam voortbestaan. Op de schaal van een landschap heeft de fragmentatie van geschikt habitat een negatief effect op de mogelijkheden voor de uitwisseling van individuen tussen populaties via migratie en dispersie. Het voorkomen van een soort in een bepaald gebied is afhankelijk van de dynamische balans tussen kolonisaties en het lokaal verdwijnen. Een balans die afhankelijk is van eigenschappen van de soort en het oppervlak en de ruimtelijke samenhang tussen de geschikte habitats. Door de uitwisseling van individuen tussen lokale populaties ontstaat een netwerk van populaties, een zogenaamde 'metapopulatie'. Bij een geringe ruimtelijke samenhang neemt de kans op lokaal uitsterven van een deelpopulatie toe waarbij geïsoleerde en of kleine populaties kwetsbaarder zijn, terwijl de kans op herkolonisatie van onbezette habitats afneemt omdat een geringere connectiviteit leidt tot een afname in dispersiesucces. Het netto-effect is dat een deel van de kenmerkende soorten geleidelijk verdwijnen uit geïsoleerde en gefragmenteerde gebieden. Dat betekent ook dat na herstel de gewenste soorten mogelijk tijdelijk maar niet duurzaam terug kunnen keren. Om een duurzame populatiegrootte te bereiken dient de habitat of van voldoende oppervlak te zijn of moeten kleinere habitats onderling voldoende verbonden worden. Dergelijke verbinding of connectiviteit kan via een corridor of via stapstenen gerealiseerd worden.

Is een veel groter habitat hersteld dan nodig voor een duurzame populatie dan kan de populatie zich zodanig ontwikkelen dat ook minder geschikte habitats in de omgeving bezet kunnen worden. Door de regelmatige aanvoer van nieuwe individuen vanuit de overtallige bronpopulatie blijven dergelijke feitelijk ongeschikte habitats toch bezet (een uitwaaieringseffect).

Netwerken van populaties kunnen samen voldoende omvang bereiken waarbij het wel noodzakelijk is de eisen van de gewenste soorten te kennen. Voor veel aquatische ongewervelden en planten is dit echter nog onvoldoende bekend.

\subsection{Prioriteitseffecten (remmende mechanismen) en andere biologische interacties en functionele rollen}

Om nieuwe ecosystemen te laten ontwikkelen, is kennis nodig over hoe soorten zich gaan vestigen in systemen en hoe soorten daar weer uit verdwijnen. Het komen en gaan van soorten is bekend van alle ecosystemen (Putnam 1994). Het vestigen is een apart probleem. Wanneer er meer soorten langer aanwezig zijn, gaan soorten interacties met elkaar aan en wordt de vestiging voor nieuwe soorten steeds moeilijker (o.a. MacArthur \& Wilson 1967). Dat heeft te maken met:

- Prioriteitseffecten: wie er het eerste is, kan de beste plekken bezetten. Hierbij spelen toevalsprocessen een grote rol.

- Interacties, als twee soorten een sterke interactie met elkaar hebben dan kan een derde daar niet meer bij (Sale 1977).

- De functionele rol van de soorten in het systeem zelf, functionele sleutelsoorten zoals ecosysteem engineers en functioneel dominante soorten (Paine 1969, Jones et al. 1994, Boyer \& Zedler 1996). Voorbeelden zijn grazers die het systeem in een bepaalde toestand houden, bevers die een stromend systeem veranderen in stilstaand of mosselen die het voedselweb van een meer kunnen wijzigen.

Dergelijke processen verlengen de tijdsduur tot het gewenste herstel. Iedere ontwikkelingstoestand bouwt meer heterogeniteit en zo weerstand op tegen veranderingen en vergroot weer zijn eigen stabiliteit en voorspelbaarheid. In systemen met veel interacties, dat zijn vaak systemen die een grote constantie vertonen en waarin biologische interacties erg belangrijk zijn, is het erg moeilijk voor nieuwe soorten om binnen te komen. Deze stabiele systemen, ie maar weinig voorkomen, zullen maar heel langzaam veranderen. In systemen waar door lichte verstoringen soms soorten verdwijnen, komt ruimte voor nieuwe soorten. In dergelijke herhaaldelijk licht verstoorde systemen zullen meer veranderingen in soortensamenstelling plaatsvinden. In nog dynamischere systemen zullen veel meer veranderingen optreden. Deze kennis is nodig om te begrijpen en te kunnen voorspellen hoe verzamelingen van soorten zich ontwikkelen na herstel. Ook is kennis nodig van aanpassingen van soorten aan al dan niet dynamische 
milieuomstandigheden, soortinteracties en levensstrategieën om te kunnen voorspellen welke soorten verwacht kunnen worden bij welke milieuomstandigheden (Fisher 1983, Hobbs \& Harris 2001).

\section{Hersteltijd en mate van herstel}

Uit het bovenstaande wordt duidelijk dat tijdvertraging bij bijna alle herstelprojecten zal optreden. De hersteltijd, de tijdvertraging na een herstelingreep, is zeer verschillend en van veel factoren afhankelijk.

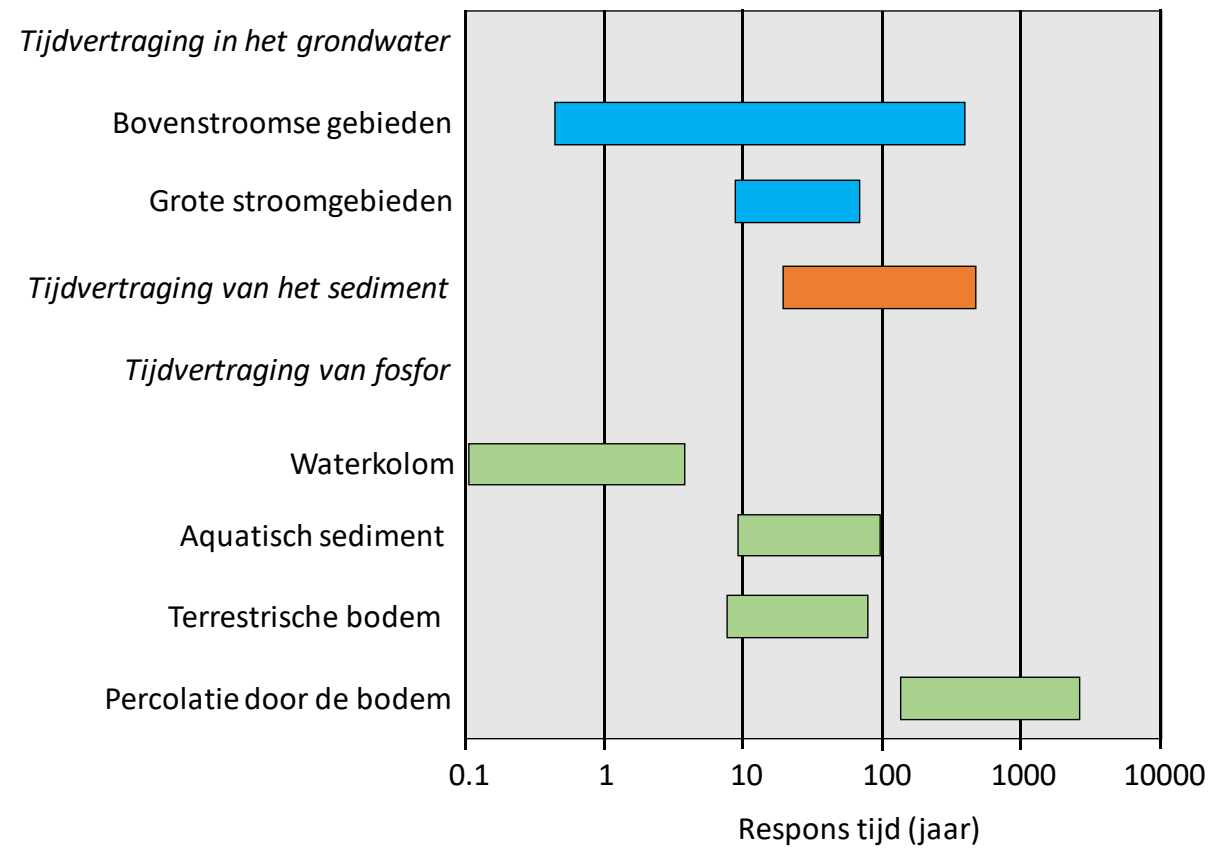

Figuur 4.1: De geschatte responstijden voor herstel van rivieren en hun stroomgebieden na verontreiniging door sediment en nutriënten. De tijdvertraging via het grondwater wordt voor circa $95 \%$ verantwoordelijk gehouden voor een volledige vervanging, gebaseerd op een driemaal gemiddelde transporttijden voor een variatie aan van stroomgebieden (naar Stewart et al. 2010). De tijdsvertragingen van sediment en fosfor zijn gebaseerd op waarnemingen en modelstudies (o.a. Schippers et al. 2006) (naar Hamilton 2011).

Schippers et al. (2006) hebben een overzicht gemaakt van de hersteltijd van een stroomgebied na een belasting met slib en nutriënten (Figuur 4.1; Hamilton 2011). Het uitgangspunt was een 95\% verversing van het grondwater waarbij een factor 3 maal de verblijftijd werd gehanteerd (Stewart et al. 2010). Ook zijn er berekeningen uitgevoerd over de vertraging in af- en uitspoeling van nutriënten en slib.

Een watersysteem hoeft niet altijd volledig te herstellen. Voor de effecten van het verwijderen van een dam in een rivier hebben Doyle et al. 2005 een conceptueel model geformuleerd (Figuur 4.2). 

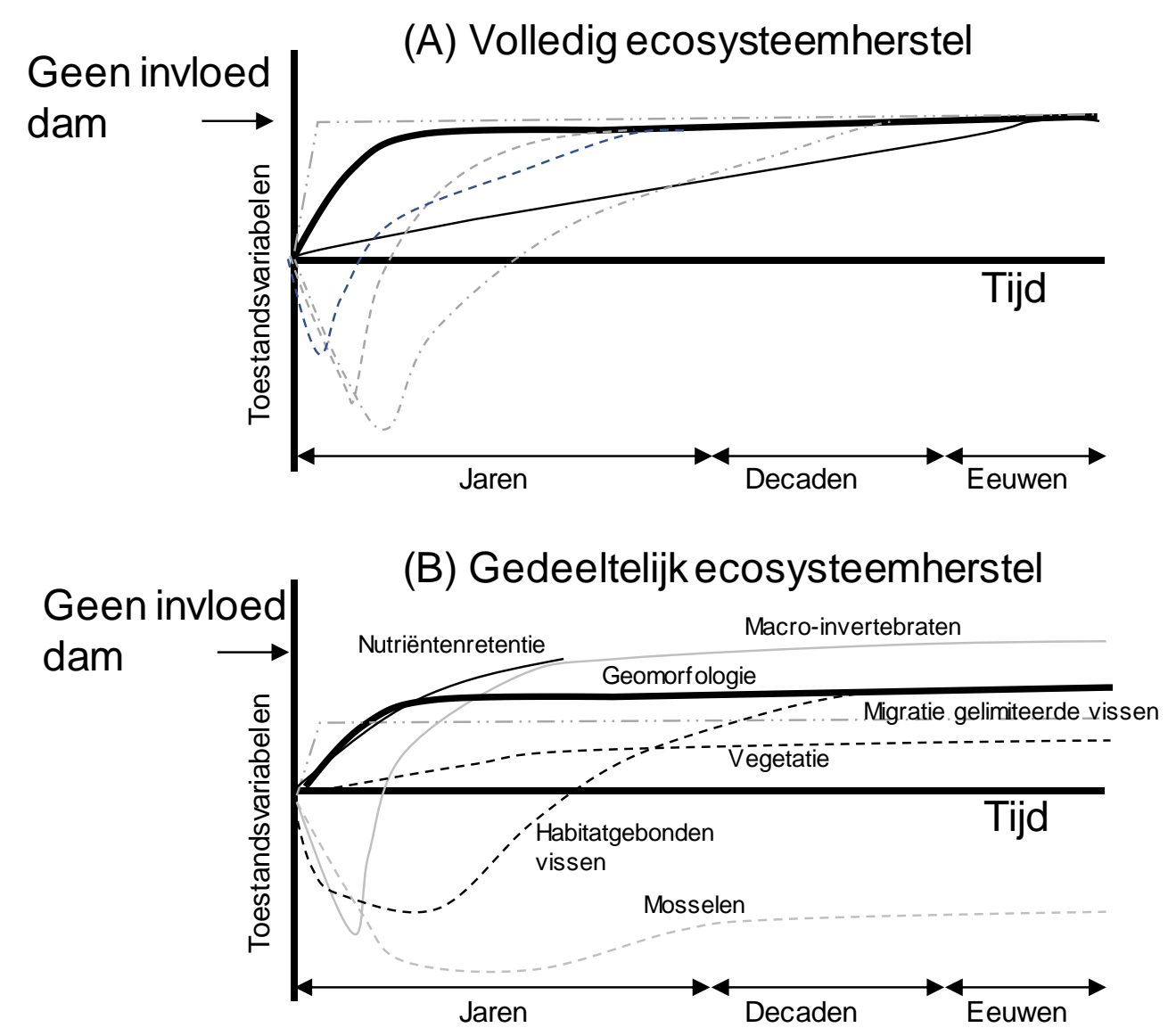

Figuur 4.2: Conceptueel verloop van ecosysteemherstel na verwijdering van een kleine dam in een rivier. Volledig ecosysteemherstel gaat ervan uit dat alle componenten van het rivier ecosysteem terugkeren naar de toestand van vóór de dam, maar met een per organismegroep wisselend hersteltraject. Gedeeltelijk ecosysteemherstel gaat ervan uit dat sommige componenten van de levensgemeenschap herstellen tot de toestand van vóór de dam, maar dat anderen slechts gedeeltelijk herstellen, terwijl weer andere beschadigd zijn door damverwijdering en niet in staat zijn helemaal te herstellen (Doyle et al. 2005).

Levensvorm

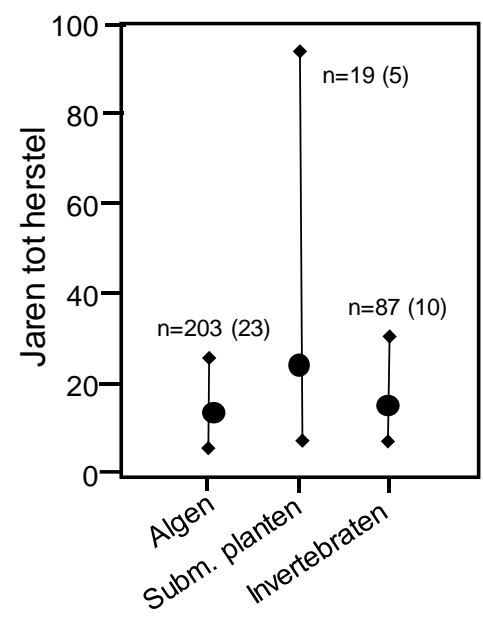

Functioneel kenmerk

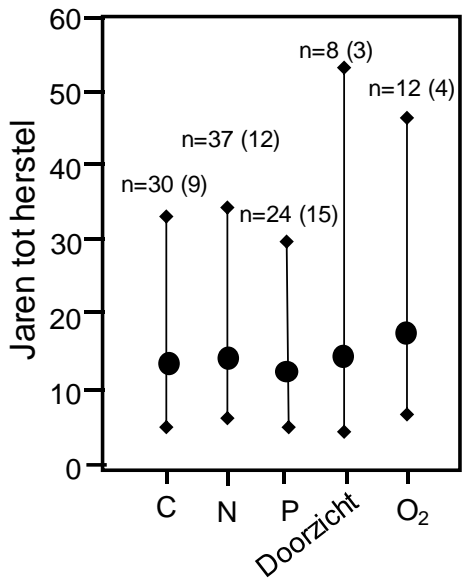

Bron nutriënten

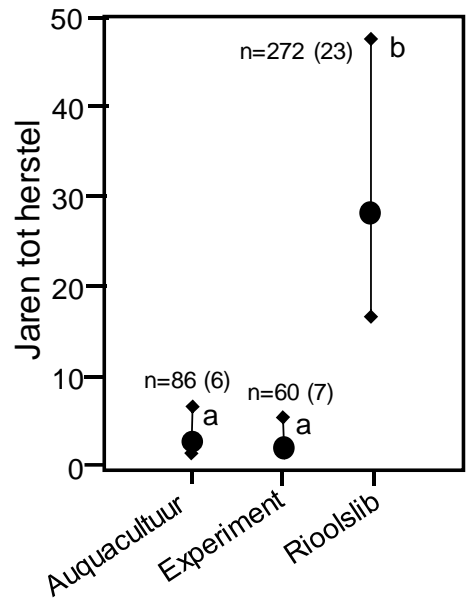

Figuur 4.3: Het aantal jaren nodig om te herstellen per responsvariabele bij het volledig wegnemen van de belasting met nutriënten ( $n=$ aantal responsvariabelen, $(x)=$ aantal onderzoeken, letter significantie $(a=0.05)$ ) (McCrackin et al. 2017). 
McCrackin et al. (2017) evalueerden de effecten op levensvormen (algen ondergedoken waterplanten en macro-invertebraten), op ecosysteem functioneren en nutriënten in 89 herstelstudies waar reductie van nutriënten in meren en kustzones plaats vond (Figuur 4.3). Slechts $34 \%$ van de projecten bereikte na decennia de streefdoelen terwijl in circa $30 \%$ geen verandering of zelfs een verslechtering optrad. In de 89 studies varieerde de hersteltijd van $<1$ jaar tot bijna een eeuw.

Er zijn maar weinig lange termijn studies van herstel in rivieren, meren en kustwateren (Verdonschot et al. 2013). Een van de belangrijkste vragen bij herstel is 'Wanneer heeft het herstel zich voltooid?'. Volledig herstel refereert naar het optimaal functioneren van het aquatische ecosysteem onder de gegeven milieu-omstandigheden zonder menselijke beïnvloeding. In stromende wateren wordt vaak naar de originele toestand gerefereerd terwijl in meren het meestal refereert aan de overgang tussen de troebele en heldere toestand. Het meeste onderzoek naar herstel strekt zich over een periode <5-10 jaar en slechts weinig studies duurden meer dan 20 jaar (Verdonschot et al. 2013). Er bestaat dus een groot verschil tussen hersteltijd en monitoringstijd, de laatste is meestal veel korter (Tabel 4.1).

Tabel 4.1: Geschatte tijd in jaren die nodig is voor volledig herstel van stromende wateren (Feld et al. 2011), meren (Spears et al., 2011) en estuariën en kustwateren (Borja et al. 2010) na een herstelingreep.

\begin{tabular}{|l|c|c|c|}
\hline & Stromende wateren & Meren & Zoute wateren \\
\hline Bacterioplankton & & $2-20$ & \\
\hline Fytoplankton & & $1->17$ & $14->22$ \\
\hline Macroalgen & & $10-20$ & Maanden \\
\hline Zoöplankton & & $2->40$ & Maanden -20 \\
\hline Meiofauna & & & $2-20$ \\
\hline Macroinvertebraten & & $2->10$ & $1-20$ \\
\hline Macrofyten & $30-40$ & $2->21$ & $15-70$ \\
\hline Oevervegetatie & & & \\
\hline Vissen & & & \\
\hline Vogels & & & \\
\hline
\end{tabular}

Bednarek (2001) concludeerde dat na het verwijderen van een dam in een rivier het meer dan 80 jaar duurt voordat volledig herstel is opgetreden. Herstel van beekbegeleidende vegetaties hebben minstens 30-40 jaar nodig om door te werken in het beeksysteem (Jowett et al. 2009). In meren heeft deeutrofiëring ongeveer 10 tot 20 jaar nodig voor de macro-invertebraten, 2 tot $>40$ jaar voor de macrofyten en 2 tot >10 jaar voor de vissen om 'hersteld' te zijn. Natuurlijk herstel na verzuring nam veel meer tijd in beslag dan herstel van verzuring door bekalken. Herstel is soort specifiek en neemt decennia of meer voor sommige, vaak specifieke, soorten. Voor sloten en kanalen, typische door de mens gegraven laagland watertypen, is weinig tot niets bekend mede omdat ze internationaal nauwelijks bestudeerd worden. Samenvattend is gemiddeld minimaal een periode van 15 tot 25 jaar nodig om de oorspronkelijke biodiversiteit en het natuurlijk functioneren in oppervlaktewateren bereikt te hebben waarbij locatie specifiek de verschillen echter veel groter kunnen zijn (Jowett et al. 2009, Borja et al. 2010, Spears et al. 2011). 


\section{Maatregelen in de context van tijdvertraging}

\subsection{Maak tijdvertraging onderdeel van het hersteltraject}

De beoordeling van de effecten van tijdvertragingen moet gebaseerd worden op de abiotische milieukwaliteit, de kwantiteit (het oppervlak) van het nieuwe habitat en de afstand en mate van verbinding (connectiviteit) tot de bronpopulatie enerzijds en de kenmerken van de soort (levensduur, aantal nakomelingen), populatiegrootte en verspreidingscapaciteit anderzijds. Om de tijdvertraging mee te nemen in een herstelproject zouden een aantal vragen vooraf beantwoord moeten worden (Bond \& Lake 2003):

Bestaan er barrières tussen bronpopulatie en te herstellen waterlichaam?

- Welke en waar zijn nog bronpopulaties aanwezig?

- Hoe kunnen eventuele barrières worden overbrugd?

- Wat zijn de habitat/leefmilieu eisen van de doelsoorten?

Welke milieu-eisen stellen de gewenste soorten?

- Hoe is de gewenste ruimtelijke configuratie van deze habitats?

Zijn er uitheemse soorten die ongelijkmatig veel van het nieuwe habitat kunnen profiteren?

- Kan de kolonisatie van deze uitheemse soorten worden voorkomen?

Welke tijdsduur en hoeveel oppervlak is nodig voor gewenst herstel?

- Geldt deze tijdvertraging voor de einddoelen of voor tussendoelen?

- Hoe wordt de tijdvertraging in de monitoring ingepast?

Hoe groot moeten de gewenste habitats zijn om de gewenste populaties van soorten, gemeenschappen, en ecosysteem functies te verkrijgen?

- Is er een minimum areaal per gewenste soort bekend?

- $\quad$ Heeft de ruimtelijke configuratie hier effect op?

\subsection{Herintroductie}

\section{Dispersiebeperkingen}

Wanneer herstel achterwege blijft door biologische factoren, zoals een gebrek aan soorten die de herstelde beek koloniseren dan is herintroductie een optie. Karakteristieke beekinsecten, zoals haften, steenvliegen en kokerjuffers, maar ook bepaalde waterplanten verspreiden zich namelijk slecht en langzaam (Downes \& Reich 2008) en hebben in het sterk veranderde en gefragmenteerde Nederlandse landschap amper mogelijkheden zich tussen wateren of stroomgebieden te verplaatsen. Een afstand van meer dan vijf kilometer tussen beken wordt genoemd als maximaal overbrugbare afstand (Sundermann et al. 2011). Het merendeel van de verplaatsingen van beekorganismen is zelfs beperkt tot de eerste kilometer vanaf loodrecht op de beek (Tonkin et al. 2014). Daarnaast zijn veel van de indicatoren teruggedrongen in kleine geïsoleerde populaties of zelfs verdwenen uit Nederland, waardoor ook nog eens het aantal potentiële kolonisten en zeer klein is. De consequentie hiervan is dat veel potentieel geschikte plekken op dit moment niet bereikt lijken te kunnen worden door de soorten die er thuishoren, ondanks dat de milieuomstandigheden er geschikt zijn.

De verspreiding van macro-invertebraten tussen stilstaande wateren zoals meren en plassen verloopt meestal passief door wind of actief door het vliegen over land (Bilton et al. 2001). Dit betekent dat nabijgelegen poelen, plassen en meren een onderling meer vergelijkbare soortensamenstelling herbergen dan dergelijke stilstaande wateren veraf (de Bie et al. 2012) ongeacht onderlinge aquatische verbindingen (Heino 2013). Desalniettemin zal ook in stilstaande wateren het milieu als filter op de vestiging werken (Leibold et al. 2004). De waarneming dat dicht bij elkaar gelegen wateren meer gelijkend zijn (ruimtelijke autocorrelatie) kan een gevolg zijn van beperkte dispersiemogelijkheden, bijvoorbeeld door beperkte dispersiecapaciteit van de soort, barrières of een beperkte tijd om een locatie te bereiken (Hubbell 2001, Heino et al. 2015) of van massa-effecten (Mouquet \& Loreau 2003, Heino 2013). Door massa-effecten kunnen nabijgelegen locaties sterk homogeniseren in samenstelling (Vilmi et al. 2016). Toch hebben in stilstaande wateren de milieu-omstandigheden het grootste effect op de samenstelling (Heino 2013). Milieufactoren zoals hardheid (calciumbeschikbaarheid voor slakken (Aho 1966)), totaal fosfor (algensamenstelling als voedsel component (Heino \& Mutka2006)), macrofyten (structuurheterogeniteit (Tolonen et al. 2001, Johnson \& Goedkoop 2002, Heino 2008)) bepalen of soorten uiteindelijk succesvol zijn of niet. Stilstaand water soorten zijn evolutionair aangepast aan het geologisch 
korter bestaan en instabieler karakter van stilstaande t.o.v. stromende wateren (Ribera \& Vogler 2000, Hof et al. 2006, Abellan et al. 2009, Damm et al. 2010). Dit betekent dat stilstaand water soorten een grotere dispersiecapaciteit zouden moeten bezitten die mogelijk samenhangt met een groter temperatuur tolerantie. Waarschijnlijk is temperatuur in stilstaande wateren de sleutelfactor voor dispersiesucces. Verstoring van de milieu-omstandigheden in stilstaande wateren vormt dan ook de belangrijkste barrière.

\section{Herintroduceren}

Vanuit ecologisch oogpunt is het simpelweg overbrengen van emmers met dieren en planten van het ene water naar het andere niet wenselijk en strijdig met de internationale richtlijnen voor het uitzetten van dieren, de zogenoemde IUCN criteria (IUCN/SSC 2013).

Wanneer er nagedacht wordt over het uitzetten van macrofauna, waterplanten en vissen in herstelde wateren, moet er eerst een goed beeld zijn van de soortensamenstelling in de regio. Bij het definiëren van het zoekgebied kan voor macro-invertebraten uit beken als vuistregel een afstand van 5 kilometer tussen beeksystemen worden genomen (Sundermann et al. 2011). Voor plantenzaden is de variatie in passieve verspreiding groot $(100 \mathrm{~m}-100 \mathrm{~km}$; Nathan et al. 2008). Vervolgens moet uitgezocht worden welke soorten precies in het gebied voorkomen en kan gekeken worden hoe deze zogenoemde 'soortenpoule' verschilt met de situatie in het verleden, maar dit blijkt meestal niet goed mogelijk. Historische data van macrofauna is namelijk zeer fragmentarisch en gaat gewoonlijk maar terug tot de jaren 1960-70, een periode waarin de degradatie van de meeste oppervlaktewateren al lang aan de gang was. Voor planten is deze tijdsperiode veel langer, behalve voor echte waterplanten. Het gebruiken van referentiesoortenlijsten, bijvoorbeeld op basis van positief kenmerkende soorten voor Nederlandse KRWmaatlatten of doelsoorten uit de Aquatische Natuurdoeltypen, is daarom een beter uitvoerbare strategie. Dit levert een lijst met in het systeem ontbrekende soorten op, maar welke soort(en) moeten gekozen worden? Het belang van de soort voor het functioneren van het ecosysteem is hierbij een belangrijk hulpmiddel. Het is aan te bevelen om de functionele voedingsgroepen als leidraad. Indien een soort een unieke rol in het systeem had en die nu niet meer door de nog aanwezige soorten vervuld wordt, komt deze soort in aanmerking om uit te zetten in het systeem (Verdonschot et al. 2014).

De volgende stap is uit te zoeken of het doelsysteem voldoet aan de eisen van de soort. Hiervoor moeten zowel de autoecologie (de ecologische relaties tussen een individueel organisme/soort en hun milieu) van de soort tot in detail uitgezocht worden alsmede de hydromorfologische, fysisch-chemische en biologische omstandigheden in het doelsysteem. Er mogen tenslotte geen knelpunten optreden ergens in de levenscyclus wil de soort zich op de lange termijn kunnen handhaven in een systeem. Het opstellen van een habitatgeschiktheidsmodel voor de soort kan hierbij een belangrijk hulpmiddel zijn. Hiermee kan ook het meest geschikte uitzetlocatie gekozen worden.

Matchen habitateisen en de omstandigheden in het doelsysteem, dan kan worden gezocht naar bestaande populaties die als bron van individuen kunnen dienen. Uit onderzoek bleek dit een problematisch onderdeel (Verdonschot \& Verdonschot 2015), en wel om twee redenen: a.) gebrek aan bronpopulaties, b.) het verzamelen van voldoende individuen. Veel potentieel geschikte kandidaten zijn namelijk of uitgestorven of zeer zeldzaam in Nederland, waardoor het niet mogelijk is voldoende individuen te verzamelen (voor macroinvertebraten adviseren we 500 individuen als minimum). Uitwijken naar het buitenland is hierbij ook een optie. Het kweken van de gewenste soorten is een alternatief, maar hiermee is nog niet veel praktijkervaring opgedaan. Voordeel van kweken is dat een groot aantal individuen tegelijkertijd kan worden uitgezet. In Engeland is bij het uitzetten van bepaalde soorten haften ook gewerkt met in het veld verzamelde en daarna in het laboratorium opgekweekte eieren (Bennett 2014).

$\mathrm{Na}$ het uitzetten is monitoring erg belangrijk. Het vastleggen van de populatieontwikkeling in de eerste jaren na het uitzetten van de dieren geeft niet alleen inzicht in het succes van het project, maar levert ook waardevolle ecologische informatie op die weer bruikbaar is voor andere projecten.

In tegenstelling tot de hoeveelheid kennis en ervaring met herintroducties van ongewervelden is veel meer ervaring opgedaan met aan water gebonden gewervelden. Zo was de otter (Lutra lutra) verdwenen uit Nederland maar is in 2002 weer uitgezet. Momenteel komt de otter weer voor in NoordwestOverijssel, Friesland, Gelderland en langs de Overijsselse Vecht. De bever was al geruime tijd uit Nederland en de meeste landen van Europa verdwenen. Dankzij herintroducties vanaf 1988 tot 2005 zijn er weer groeiende populaties bevers in Nederland aanwezig. Bij doorzettende populatie ontwikkeling is de verwachting dat binnen 10 jaar een aaneengesloten beverpopulatie in het Nederlandse rivierengebied aanwezig is. Andere potentiële bever habitats elders in Nederland worden vroeg of laat spontaan gekoloniseerd. De succesvolle herintroductie duidt aan dat de leefomstandigheden voor deze soorten weer voldoende zijn tegelijk laat het ook zien dat deze soorten niet zozeer direct van de waterkwaliteit, behalve enkele toxische stoffen, afhankelijk zijn maar vooral van verbetering van andere factoren op grotere schaal. 


\subsection{Adaptieve monitoring}

Om met tijdvertraging in het achterhoofd streefdoelen te bepalen is het belangrijk onderscheid te maken tussen generalisten, specialisten en gevoelige soorten en deze kennis te gebruiken. Gezien de lange tijdschaal waarop herstel vaak pas zichtbaar wordt zijn tussendoelen noodzakelijk. Tussendoelen fungeren als stappen in de richting van het streefdoel. Een stappenplan zou er as volgt uit kunnen zien:

Tussendoel 1: Het opstellen van een herstelvisie en -plan voor een ruimtelijk grootschalige hydrologische eenheid, zoals een geheel stroomgebied met deelstroomgebieden of een complex aan polders in een boezemstelsel of een complex van plassen en meren, allen met hun omgeving en alle waterelementen. Het identificeren van de gevoelige soorten die op korte termijn versterking van de populaties nodig hebben, bijvoorbeeld de gevoelige KRW-indicatoren.

Stap 1.1: Het bepalen van de benodigde kwaliteit van het leefmilieu (milieu- en habitatkwaliteit) conform de milieu-eisen van de soort(en), de dispersiecapaciteit in relatie tot de benodigde connectiviteit en het vaststellen de soort-oppervlak relaties.

Stap 1.2: Het herstellen van meerdere wateren in onderling voldoende verbinding waar de gevoelige soort(en) in actief of passief (uitzetten, terugplaatsen) kan/kunnen terugkeren.

Tussendoel 2: Wateren van voldoende omvang, milieu- en habitatkwaliteit en ruimtelijke positionering (configuratie voor een metapopulatie) zijn gerealiseerd (het herstelplan is uitgevoerd) en de gevoelige soorten hebben (theoretisch) de mogelijkheid zich te vestigen en uit te breiden. Meten en modelstudies tonen aan dat de gewenste soorten zich zouden kunnen ontwikkelen.

Tussendoel 3: Door te monitoren is aangetoond dat de generalisten zich in het herstelde water hebben gevestigd.

Tussendoel 4: De milieu-omstandigheden in het herstelde gebied ontwikkelen zich in de beoogde richting, bijvoorbeeld ontwikkelt zich de gewenste habitatheterogeniteit en de populaties van generalisten stabiliseren.

Tussendoel 5: De specialisten vestigen zich in de wateren en de eerste gevoelige soorten keren terug.

Met doorlopende doelgerichte tijdreeksmonitoring van geschikte indicatoren van tussendoelen en het streefdoel kan het ontwikkelingsproces worden steeds tussentijds worden ge-evalueerd en tussentijds waar nodig worden bijgesteld. Ook kan de voortgang nauwkeurig worden gerapporteerd. Bij afwijkingen kan worden bijgestuurd (adaptieve monitoring en beheer). 


\section{Literatuur}

Bednarek, A. T. (2001). Undamming rivers: a review of the ecological impacts of dam removal. Environmental management, 27(6), 803-814.

Bennett, C. (2014) Conservation report 2014. Salisbury \& District Angling Club/Centre for Riverfly Conservation, Salisbury.

Bilton, D. T., Freeland, J. R., \& Okamura, B. (2001). Dispersal in freshwater invertebrates. Annual review of ecology and systematics, 32(1), 159-181.

Bond, N. R., \& Lake, P. S. (2003). Local habitat restoration in streams: constraints on the effectiveness of restoration for stream biota. Ecological Management \& Restoration, 4(3), 193-198.

Borja, Á., Elliott, M., Carstensen, J., Heiskanen, A. S., \& van de Bund, W. (2010). Marine management-towards an integrated implementation of the European Marine Strategy Framework and the Water Framework Directives. Marine pollution bulletin, 60(12), 2175-2186.

Boyer, K. E., \& Zedler, J. B. (1996). Damage to cordgrass by scale insects in a constructed salt marsh: effects of nitrogen additions. Estuaries, 19(1), 1-12.Burroughs et al. 2009

Cornell, H. V., \& Lawton, J. H. (1992). Species interactions, local and regional processes, and limits to the richness of ecological communities: a theoretical perspective. Journal of animal ecology, 1-12.

Crane, S. R., Moore, J. A., Grismer, M. E., \& Miner, J. R. (1983). Bacterial pollution from agricultural sources: a review. Transactions of the ASAE, 26(3), 858-0866.

Cristofoli, S. \& Mahy, G. (2010). Colonisation credit in recent wet heathland butterfly communities. Insect Conserv. Divers. 3, 83-91.

Dørge, J., \& Windolf, J. (2003). Implementation of the water framework directive-can we use models as a tool in integrated river basin management?. International Journal of River Basin Management, 1(2), 165-171.

Downes, B.J., Reich, P. (2008) What is the spatial structure of stream insect populations? Dispersal behavior at different life-history stages. P. 184-203. In: Lancaster, J \& Briers, R.A. (eds.) Aquatic insects: challenges to populations. CABI, Wallingford.

Doyle, M. W., Stanley, E. H., Orr, C. H., Selle, A. R., Sethi, S. A., \& Harbor, J. M. (2005). Stream ecosystem response to small dam removal: lessons from the Heartland. Geomorphology, 71(1-2), 227-244.

Feld, C.K., Birk, S., Bradley, D.C., Hering, D., Kail, J., Marzin, A., Melcher, A., Nemitz, D., Pedersen, M.L., Pletterbauer, F., Pont, D., Verdonschot, P.F.M. \& Friberg, N., 2011. From Natural to Degraded Rivers and Back Again: A Test of Restoration Ecology Theory and Practice. Advances in Ecological Research 44: 120209.

Figueiredo, L., Krauss, J., Steffan-Dewenter, I. \& Sarmento Cabral, J. (2019). Understanding extinction debts: spatio-temporal scales, mechanisms and a roadmap for future research. Ecography 42, 1973-1990.

Fisher, S.G., 1983. Succession in streams. In: Barnes JR, Minshall GW (eds) Stream ecology: application and testing of general ecological theory. Plenum Press, NY pp 7-27

Friberg, N., Angelopoulos, N. V., Buijse, A. D., Cowx, I. G., Kail, J., Moe, T. F., ... \& Wolter, C. (2016). Effective river restoration in the 21st century: from trial and error to novel evidence-based approaches. In Advances in Ecological Research (Vol. 55, pp. 535-611). Academic Press.

Froelich, P. N. (1988). Kinetic control of dissolved phosphate in natural rivers and estuaries: a primer on the phosphate buffer mechanism 1. Limnology and oceanography, 33(4part2), 649-668.

Genkai-Kato, M., \& Carpenter, S. R. (2005). Eutrophication due to phosphorus recycling in relation to lake morphometry, temperature, and macrophytes. Ecology, 86(1), 210-219.Clements, F. E. (1916). Plant succession: an analysis of the development of vegetation (No. 242). Carnegie Institution of Washington.

Gleason, H.A., 1917. The structure and development of the plant association. Bull. Torrey Bot. Club 44: $463-481$.

Godsey, S. E., Aas, W., Clair, T. A., De Wit, H. A., Fernandez, I. J., Kahl, J. S., ... \& Norton, S. A. (2010). Generality of fractal $1 / \mathrm{f}$ scaling in catchment tracer time series, and its implications for catchment travel time distributions. Hydrological Processes, 24(12), 1660-1671.

Gore, J. A., \& Milner, A. M. (1990). Island biogeographical theory: can it be used to predict lotic recovery rates?. Environmental Management, 14(5), 737-753.

Gore, J. A., \& Milner, A. M. (1990). Island biogeographical theory: can it be used to predict lotic recovery rates?. Environmental Management, 14(5), 737-753.

Haygarth, P. M., Condron, L. M., Heathwaite, A. L., Turner, B. L., \& Harris, G. P. (2005). The phosphorus transfer continuum: linking source to impact with an interdisciplinary and multi-scaled approach. Science of the total environment, 344(1-3), 5-14.

Heywood, V. H., Mace, G. M., May, R. M., and Stuart, S. N. 1994. Uncertainties in extinction rates. Nature 368:105.

Hobbs, R. J., \& Harris, J. A. (2001). Restoration ecology: repairing the earth's ecosystems in the new millennium. Restoration ecology, 9(2), 239-246. 
IUCN/SSC (2013) Guidelines for Reintroductions and Other Conservation Translocations. Version 1.0. IUCN Species Survival Commission, Gland.

Jackson, S. T. \& Sax, D. F. (2010). Balancing biodiversity in a changing environment: extinction debt, immigration credit and species turnover. Trends Ecol. Evol. 25, 153-160.

Jähnig, S. C., Brabec, K., Buffagni, A., Erba, S., Lorenz, A. W., Ofenböck, T., ... \& Hering, D. (2010). A comparative analysis of restoration measures and their effects on hydromorphology and benthic invertebrates in 26 central and southern European rivers. Journal of Applied Ecology, 47(3), 671-680.

Jarvie, H. P., Mortimer, R. J., Palmer-Felgate, E. J., Quinton, K. S., Harman, S. A., \& Carbo, P. (2008). Measurement of soluble reactive phosphorus concentration profiles and fluxes in river-bed sediments using DET gel probes. Journal of hydrology, 350(3-4), 261-273.

Jeppesen, E., Søndergaard, M., Jensen, J. P., Havens, K. E., Anneville, O., Carvalho, L., ... \& Gerdeaux, D. (2005). Lake responses to reduced nutrient loading-an analysis of contemporary long-term data from 35 case studies. Freshwater Biology, 50(10), 1747-1771.

Jeppesen, E., Søndergaard, M., Meerhoff, M., Lauridsen, T. L., \& Jensen, J. P. (2007). Shallow lake restoration by nutrient loading reduction-some recent findings and challenges ahead. In Shallow Lakes in a Changing World (pp. 239-252). Springer, Dordrecht.

Jones CG, Lawton JH, Shachak M. 1994. Organisms as ecosystem engineers. Oikos 69: 373-386.

Jowett, I. G., Richardson, J., \& Boubee, J. A. T. (2009). Effects of riparian manipulation on stream communities in small streams: two case studies. New Zealand Journal of Marine and Freshwater Research, 43(3), 763774.

Kolk, J., Naaf, T. \& Wulf, M. (2017). Paying the colonization credit: converging plant species richness in ancient and post-agricultural forests in NE Germany over five decades. Biodivers. Conserv. 26, 735-755.

Krauss, J. et al. (2010). Habitat fragmentation causes immediate and time-delayed biodiversity loss at different trophic levels. Ecol. Lett. 13, 597-605.

Kuussaari, M. et al. (2009). Extinction debt: a challenge for biodiversity conservation. Trends Ecol. Evol. 24, 564571.

Lira, P. K., de Souza Leite, M. \& Metzger, J. P. (2019). Temporal lag in ecological responses to landscape change: where are we now? Curr. Landsc. Ecol. Rep. 4, 70-82

MacArthur, R.H. \& Wilson, E.O., 1967. The Theory of Island Biogeogaphy. Monographs in Population Biology, Princeton Univ.

Mainstone, C. P., \& Parr, W. (2002). Phosphorus in rivers-ecology and management. Science of the Total Environment, 282, 25-47.

Malmqvist, B. (2002). Aquatic invertebrates in riverine landscapes. Freshwater Biology, 47(4), 679-694.

Marsden, M. W. (1989). Lake restoration by reducing external phosphorus loading: the influence of sediment phosphorus release. Freshwater Biology, 21(2), 139-162.

McCrackin, M. L., Jones, H. P., Jones, P. C., \& Moreno-Mateos, D. (2017). Recovery of lakes and coastal marine ecosystems from eutrophication: A global meta-analysis. Limnology and Oceanography, 62(2), 507-518.

McGuire, K. J., \& McDonnell, J. J. (2006). A review and evaluation of catchment transit time modeling. Journal of Hydrology, 330(3-4), 543-563.

McMahon, P. B., Dennehy, K. F., Bruce, B. W., Böhlke, J. K., Michel, R. L., Gurdak, J. J., \& Hurlbut, D. B. (2006). Storage and transit time of chemicals in thick unsaturated zones under rangeland and irrigated cropland, High Plains, United States. Water Resources Research, 42(3).

Meals, D. W. (2001). Water quality response to riparian restoration in an agricultural watershed in Vermont, USA. Water Science and Technology, 43(5), 175-182.

Meals, D. W., Dressing, S. A., \& Davenport, T. E. (2010). Lag time in water quality response to best management practices: A review. Journal of environmental quality, 39(1), 85-96.

Michel Jr, F. C., Pecchia, J. A., Rigot, J., \& Keener, H. M. (2004). Mass and nutrient losses during the composting of dairy manure amended with sawdust or straw. Compost Science \& Utilization, 12(4), 323-334.

Nathan, R., Schurr, F. M., Spiegel, O., Steinitz, O., Trakhtenbrot, A., \& Tsoar, A. (2008). Mechanisms of longdistance seed dispersal. Trends in ecology \& evolution, 23(11), 638-647.

Neal, C., Jarvie, H. P., Withers, P. J., Whitton, B. A., \& Neal, M. (2010). The strategic significance of wastewater sources to pollutant phosphorus levels in English rivers and to environmental management for rural, agricultural and urban catchments. Science of the Total Environment, 408(7), 1485-1500.

Newbold, J.D., S. Herbert, B.W. Sweeney, and P. Kiry. 2008. Water quality functions of a 15-year-old riparian forest buff er system. p. 1-7. In Riparian ecosystems and buffers: Working at the water's edge. AWRA Summer Specialty Conf. Am. Water Resources Assoc., Virginia Beach, VA.

Northcote, T. G. (1998). Migratory behaviour of fish and its significance to movement through riverine fish passage facilities. Fish migration and fish bypasses, 3.

Odum, E.P., 1969. The strategy of ecosystem development. Science 164: 262-270. 
Orr, C.H., 2002. Patterns of removal and ecological response: a study of small dams in Wisconsin. MS thesis, University of Wisconsin, Madison.

Paine, R.T., 1969. A note on trophic complexity and community stability. The American Naturalist 1103: 91-93.

Phillips, G., Kelly, A., PITT, J. A., Sanderson, R., \& Taylor, E. (2005). The recovery of a very shallow eutrophic lake, 20 years after the control of effluent derived phosphorus. Freshwater Biology, 50(10), 1628-1638.

Pickett, S.T.A., Collins, S.L. \& Armesto, J.J., 1987. A hierarchical consideration of causes and mechanisms of succession. Vegetatio 69: 109-114.

Pickett, S.T.A., Kolasa, J., Armesto, J.J. \& Collins, S.L., 1989. The Ecological Concept of Disturbance and its Expression at Various Hierarchical Levels. Oikos 54: 129-136.

Putnam, R.J., 1994. Community ecology. Chapman and Hall, London.

Rao, P.S.C., A.G. Hornsby, and R.E. Jessup. 1985. Indices for ranking the potential for pesticide contamination of groundwater. Proc. Soil Crop Sci. Soc. Fla. 44:1-8.

Reddy, K. R., Diaz, O. A., Scinto, L. J., \& Agami, M. (1995). Phosphorus dynamics in selected wetlands and streams of the Lake Okeechobee Basin. Ecological Engineering, 5(2-3), 183-207.

Reddy, K. R., Kadlec, R. H., Flaig, E., \& Gale, P. M. (1999). Phosphorus retention in streams and wetlands: a review. Critical reviews in environmental science and technology, 29(1), 83-146.

Sale, P. F. (1977). Maintenance of high diversity in coral reef fish communities. The American Naturalist, 111(978), 337-359.

Sand-Jensen, K., Bruun, H. H., \& Baastrup-Spohr, L. (2017). Decade-long time delays in nutrient and plant species dynamics during eutrophication and re-oligotrophication of Lake Fure 1900-2015. Journal of Ecology, 105(3), 690-700.

Schippers, P., Van de Weerd, H., De Klein, J., De Jong, B., \& Scheffer, M. (2006). Impacts of agricultural phosphorus use in catchments on shallow lake water quality: about buffers, time delays and equilibria. Science of the Total Environment, 369(1-3), 280-294.

Schumm, S.A. (1977). The fluvial system. John Wiley and Sons, New York.

Sherer, B. M., Miner, J. R., Moore, J. A., \& Buckhouse, J. C. (1992). Indicator bacterial survival in stream sediments. Journal of Environmental Quality, 21(4), 591-595.

Simon, A., 1992. Energy, time, and channel evolution in catastrophically disturbed fluvial systems. Geomorphology 5: $345-372$.

Smolders, A. J. P., Lamers, L. P. M., Lucassen, E. C. H. E. T., Van der Velde, G., \& Roelofs, J. G. M. (2006). Internal eutrophication: how it works and what to do about it-a review. Chemistry and ecology, 22(2), 93-111.

Søndergaard, M., Jeppesen, E., Lauridsen, T. L., Skov, C., Van Nes, E. H., Roijackers, R., ... \& Portielje, R. O. B. (2007). Lake restoration: successes, failures and long-term effects. Journal of Applied ecology, 44(6), 1095-1105.

Spears, B. M., Carvalho, L., Perkins, R., Kirika, A., \& Paterson, D. M. (2011). Long-term variation and regulation of internal phosphorus loading in Loch Leven. In Loch Leven: 40 years of scientific research (pp. 23-33). Springer, Dordrecht.

Stefan, H. G., \& Preud'homme, E. B. (1993). Stream temperature estimation from air temperature 1. JAWRA Journal of the American Water Resources Association, 29(1), 27-45.

Stewart, M. K., Morgenstern, U., Gusyev, M. A., \& Małoszewski, P. (2017). Aggregation effects on tritium-based mean transit times and young water fractions in spatially heterogeneous catchments and groundwater systems. Hydrology and Earth System Sciences, 21(9), 4615.

Suding, K.N. \& Gross, K.L., 2006. The dynamic nature of ecological systems: multiple states and restoration trajectories. In: D.A. Falk, M.A. Palmer \& J.B. Zedler, Foundations of restoration ecology, 9: 190-209.

Sundermann, A., Stoll, S., Haase, P. (2011) River restoration success depends on the species pool of the immediate surroundings. Ecological Applications 21:1962-1971.

Sutherland, J.P., 1974. Multiple stable points in natural communities. American Naturalist 108:859-873.

Tilman, D., May, R. M., Lehman, C. L. \& Nowak, M. A. (1994). Habitat destruction and the extinction debt. Nature $371,65-66$.

Tonkin, J.D., Stoll, S., Sundermann, A., Haase, P. (2014) Dispersal distance and the pool of taxa, but not barriers, determine the colonisation of restored river reaches by benthic invertebrates. Freshwater Biology 59: $1843-1855$.

Trimble, S.W. 2010. Streams, valleys and floodplains in the sediment cascade. In: Burt, T., and Allison, R., editors, Sediment cascades: An integrated approach. John Wiley \& Sons, Oxford, UK.

Ulén, B., \& Jakobsson, C. (2005). Critical evaluation of measures to mitigate phosphorus losses from agricultural land to surface waters in Sweden. Science of the Total Environment, 344(1-3), 37-50.

Verdonschot, P. F. M., Spears, B. M., Feld, C. K., Brucet, S., Keizer-Vlek, H., Borja, A., ... \& Johnson, R. K. (2013). A comparative review of recovery processes in rivers, lakes, estuarine and coastal waters. Hydrobiologia, 704(1), 453-474. 
Verdonschot, R. C. M., \& Verdonschot, P. F. M. (2015). Het uitzetten van macrofauna als beekherstelmaatregel. $\mathrm{H} 2 \mathrm{O}$ online, (3 oktober).

Verdonschot, R.C.M., Kleef, H.H. van, Verdonschot, P.F.M. (2014) Herstel van laaglandbeken door het herintroduceren van macrofauna. 2014 Rapport nr. 2015/OBN199-BE, Vereniging van Bos- en Natuurterreineigenaren, Driebergen.

Watts, K., Whytock, R. C., Park, K. J., Fuentes-Montemayor, E., Macgregor, N. A., Duffield, S., \& McGowan, P. J. (2020). Ecological time lags and the journey towards conservation success. Nature Ecology \& Evolution, $1-8$.

Withers, P. J. A., \& Jarvie, H. P. (2008). Delivery and cycling of phosphorus in rivers: a review. Science of the total environment, 400(1-3), 379-395.

Worrall F., Spencer E. \& Burt T.P. (2009a) The effectiveness of nitrate vulnerable zones for limiting surface water nitrate concentrations. Journal of Hydrology, 370, 21-28.

Zhang, J. Z., Fischer, C. J., \& Ortner, P. B. (2004). Potential availability of sedimentary phosphorus to sediment resuspension in Florida Bay. Global Biogeochemical Cycles, 18(4). 